\title{
The Lion, the Shepherd, and the Master of Animals: METAPHORICAL INTERACTIONS AND Governance Representations in Mesopotamian AND LEVANTINE SOURCES
}

\author{
Stéphanie Anthonioz (Université catholique de Lille, UMR 8167)
}

As Brent A. Strawn reminds us, metaphor theory has cast significant light on the interpretation of metaphors and the way they function. ${ }^{.}$This can be briefly summarized in the following way: metaphor is a literary figure that speaks of one thing (A) by means of another (B). The relationship between $A$ and $B$ creates a complex interaction with the transfer of some or all of B's qualities to $A$ with the consequence that $B$ may be likened to A. This interaction between elements could in theory be extended to different metaphors that have at least one element in common. For example, if the king $(\mathrm{A})$ is associated with the image of the lion (B) in different sources but also to that of the shepherd (C), one could no longer consider these metaphors in a separate way $(\mathrm{A} / \mathrm{B}$ and $\mathrm{A} / \mathrm{C})$ but in their interaction $(\mathrm{A} / \mathrm{B} / \mathrm{C})$. The shepherd and the lion are images as well as vivid metaphors which have each received much attention. ${ }^{2}$ Closely connected to the lion and the shepherd stands the image of the Master of animals which is less documented, ${ }^{3}$ possibly because of the fewer textual sources referring to it. It is obvious that these images are those that represent power in the ancient Near East and particularly royal and divine power. This is true also in Greece as documented by Johannes Haubold, ${ }^{4}$ who, for example, explores the pastoral theme according to Foucault's concept of pastoralism and studies how it is reworked in two ancient literary texts, Gilgames and the Iliad. ${ }^{5}$ However, these metaphors have rarely been studied in their interaction. One important and as yet peerless study has,

* I would like to thank Márton Farkas for his careful reading of this contribution and improving my English.

I Strawn 2005, I-I5.

2 Strawn 2009 and 2015; Pyper 2014; Nahkola 201 I; Albenda 1972, 1974, and 2008; Seyer 2006 and 2007; Watanabe 1998 and 2000; Collins 1998; Cassin 1981. Concerning the image of the shepherd, see footnote 37 .

3 Selz 2018; Counts and Arnold (eds.) 2010; Diamond 2003; Keel and Uehlinger 2001, I83-I92.

4 Haubold 2015; Heil 2006.

5 Haubol 2015. According to the author, Greek and Mesopotamian authors participated in a longstanding debate about pastoral leadership which spanned the Eastern Mediterranean and Near East. Homer and Gilgameš describe the problem in similar terms, but they disagree on how it can be 
however, been published: The Master of Animals in Old World Iconography, edited by Derek B. Counts and Bettina Arnold, lays the fundament for such an endeavor. ${ }^{6}$ As the authors remind us, in the realm of iconography, the image of the master of animals in its diversity has enjoyed wide-ranging popularity. Indeed, this very image allowed for the articulation of various concepts in binary opposition so essential to social, political and religious representations, such as human vs. nature; earthly vs. divine; strength vs. weakness; authority vs. subordination; wild vs. tamed; life vs. death; and order vs. chaos. The Master of animals manifests royal power and the maintenance of order in the cosmos through nature. In a stimulating manner, in Cyprus, the case for the re-appropriation of a Master of animals into a shepherd - the good shepherd as the Christian context makes clear - is attested. ${ }^{7}$ In this case, the re-appropriation was easy since the qualities of element $\mathrm{B}$, the Master of animals, did overlap with those of element $\mathrm{C}$, the good shepherd, element A, being the common element to both images, the sovereign lord.

As far as I am aware, the images of the lion, the shepherd, and the Master of animals, though closely associated in the realm of sovereignty, have not been the object of what could be called an associative or interactive analysis. This contribution aims at revisiting these images, analyzing the sources in interaction, without excluding them and confronting them even in their contradictions. The following analysis is based on textual sources and should be further enriched by the study of iconographic sources. In the first part, I will review Assyrian royal inscriptions and their treatment of the figures of the lion and the shepherd. In the second part, I will review Levantine sources, which will allow me to propose, in the Book of Amos, a detailed analysis of the interactive metaphors of the lion and the shepherd.

\section{The Lion in Mesopotamian Royal Inscriptions 8}

There is no doubt that the metaphorical dimension of the leonine figure is of great antiquity in Mesopotamian sources. It is often associated with the hunt and this point has been abundantly studied and theorized. ${ }^{9}$ In royal inscriptions from the Medio-Assyrian peri-

addressed. This, then, is my third point: while the epic of Gilgameš suggests that the shepherd can be reformed, Greek epic is far less optimistic.

6 Counts and Arnold 2010.

7 "The presence of this ostensibly pagan image in a secondary context raises some interesting questions with respect to the transition from paganism to Christianity in Cyprus. The appropriation of pagan religious iconography within Early Christian symbolism is a common one, and the weight of the evidence here suggests the statuette may have provided a suitable icon for a Christian god who was now worshiped as the 'Good Shepherd"' (Counts 2010, 135).

8 Seux 1967, in particular pp. I47-148 and 436-437 (labbu, PIRIG, 'lion').

9 "Kings undertook this activity at all times for a wide variety of reasons such as for amusement and sportive activity. It formed not only a privilege but also an obligation for them, because in so doing they had to meet the demands, which were assigned to them as the ruler of their people. Therefore the hunt gained particular importance in the life of the royal court. Precisely because of the prominence which it gained as actual exercise for kings, it also developed into a literary and artistic topos, which might display a manifold symbolism, but need not be connected with actual hunting events. The ideas which are associated with the royal hunt trace their origins back to the cultures of the an- 
od, the lion is indeed present through the motif of the royal hunt, among other animals. At this point, one should be reminded that this figure is not metaphorical: "The gods Ninurta and [Nergal, who love my priesthood, gave to me the wild beasts and commanded me to hunt]. 300 lions [... with my fierce] valor [...] six strong [wild] virile [bulls] with horns [... from my ... chariot] and on [my swift] feet, [in my] second regnal year, [... with my] sharp [arrows] I [... The remainder of the numerous animals] and the winged birds of the sky, [wild game which I acquired, their names are not written with these] animals, [their numbers are not written with these numbers]" (Aššur-bel-kala 02, iii 29'). ${ }^{\text {10 }}$

Clearly the royal hunt is an organized event and is associated with the gathering of herds of diverse species (Aššur-bel-kala 07, iv). This organization is also a royal demonstration as the king enters the stage to be victorious in the eyes of all, his people, vassals and enemies. In this way, the scene recreates a microcosm of the world: the animals represent the forces of the universe, both positive and negative ones.

Lions are also part of the architecture of Assyrian buildings and, interestingly, texts bear testimony to this visual representation of the cosmic empire and its well-ordered movement from center to periphery. The animals are messengers of both aggression and protection: they defend the palace in a double manner. They (somehow) endow the monuments and their resident with their very power and terror. This analysis is based on the inscriptions from the reign of Ašsur-bel-kala, yet it is confirmed by the inscriptions from the reigns of Aššur-reša-iši, Šamši-Adad IV and Tiglath-pileser $I^{\text {II }}$ as well as from those of the Neo-Assyrian period, Adad-nerari III, Aššur-dan II, Ashurnasirpal Tiglath-pileser III, and Sennacherib. ${ }^{12}$ One may note, moreover, in the inscriptions from Ashurnasirpal II the apparition of the royal and leonine title: "At that time my sovereignty, my dominion, (and) my power came forth at the command of the great gods; I am king, I am lord, I am praiseworthy, I am exalted, I am important, I am magnificent, I am foremost, I am a hero, I am a warrior, I am a lion, and I am virile; Ashurnasirpal, strong king, king of Assyria, designate of the god Sîn, favorite of the god Anu, loved one of the god Adad (who is) almighty among the gods, I, the merciless weapon which lays low lands hostile to him, I, the king, capable in battle, vanquisher of cities and highlands" (Ashurnasirpal II ooI, I $3 \mathrm{Ib}$ ). ${ }^{\mathrm{I3}}$

cient Near East; (...) the same ideas were not only perpetuated during the reign of the Achaemenids, after the conquest of the Assyrian and the Neo-Babylonian Empires by Cyrus the Great, but also conveyed the same meaning in the time of Alexander the Great and his diadochs, and, furthermore, were consciously utilised for political reasons" (Seyer 2006, I7 I-I72).

IO See Aššur-bel-kala 03, I’. All Assyrian royal inscriptions are quoted from The Royal Inscriptions of Assyria online (RIAo) Project: http://oracc.museum.upenn.edu/riao/

I I Aššur-reša-iši I oI, 8; O2, 3 (lions at the entrance of the temple of Ištar), Šamši-Adad IV 3, I' (monumental lions), Tiglath-pileser I oI, vi 76 (hunt).

I2 Adad-nerari III 20IO, I9 (monumental lions), Aššur-dan II I, 68 (hunt), Ashurnasirpal II oo2, 3I (hunt and zoo); 002, 35 (zoo); 002, 40 (hunt); 019, 30 (hunt); 028, v 7b (religious architecture); 030, $84 \mathrm{~b}$ (hunt); 030, 95 (breeding); Tiglath-pileser III 47, r 29’b (architecture); 200I, I (architecture), Sennacherib I, 83; 2, 60; I5, vi 6I; I6, vi 74; I7, vi 89; I7, vii 9; I7, vii 26; 39, 5I 40, 37'b; 4I, 2'; 42, 22'; 42, 28'b; 42, 33’b; 43, 73; 43, 79b; 43, 85b (architecture).

See also Ashurnasirpal II or 7 , i 35; 020, 4 ob. 
The title knows of a particular development especially in Sennacherib's inscriptions: "When they reported his (Marduk-apla-iddina's) evil deeds to me, Sennacherib, the attentive man of the steppe, I raged up like a lion and ordered the march into Babylon to confront him. He (Marduk-apla-iddina), the (very) image of an evil gallû-demon, heard about the advance of my expeditionary force, then he reinforced their companies with horses (and) Elamite, Aramean, (and) Chaldean archers" (Sennacherib I, I6). ${ }^{14}$

Though not all references to lions documented in the sources are metaphors, the image develops in a metaphorical way, endowing the Assyrian king with the qualities and force of the lion. However, the leonine metaphor is not unique in representing royal and imperial governance of the world.

\section{The Shepherd in Mesopotamian Royal Inscriptions}

In Mesopotamia, Akkadian rềtu or 'shepherdship' is the office divinely created for the benefit of humankind. In the Epic of Etana Ištar goes in search of a shepherd at the beginning of history, and the same idea is found in the Graeco-Babylonian author Berossos. The role of the shepherd as divinely sanctioned is essential and even rulers who are themselves outsiders, as Cyrus the Great, for example, portrayed themselves as shepherd (cf. Cyrus Cylinder).

The image of the shepherd is found in the royal titles all through the medio- and neo-Assyrian periods. ${ }^{15}$ Thus Aššur-nādin-apli proclaims: "Aššur-nādin-apli, appointee of the god Enlil, vice-regent of the god Aššur, strong king, king of all people, prince, king of kings, faithful shepherd, to whom by the command of the gods Aššur, Enlil, and Šamaš the just scepter was given and whose important name was called for the return of the land, the king under the protective hand of the god Anu and select of the god Enlil, chosen of the gods Aššur and Šamaš, I, son of Tukultī-Ninurta (I), appointee of the god Enlil, vice-regent of the god Aššur; son of Shalmaneser (I) (who was) also appointee of the god Enlil (and) vice-regent of the god Aššur” (Aššur-nadin-apli I, I).

If the image of the 'faithful shepherd' is frequent, ${ }^{16}$ many variants are attested: 'shepherd of all the settlements', ${ }^{17}$ 'shepherd of mankind', ${ }^{18}$ 'attentive shepherd', ${ }^{19}$ 'chief herdsman', ${ }^{20}$ 'pious shepherd', ${ }^{21}$ and later on 'capable shepherd', ${ }^{22}$ 'obedient shepherd', ${ }^{23}$ 'shepherd of the black-headed', ${ }^{24}$ 'true shepherd'. ${ }^{25}$ The image is further developed: 'for

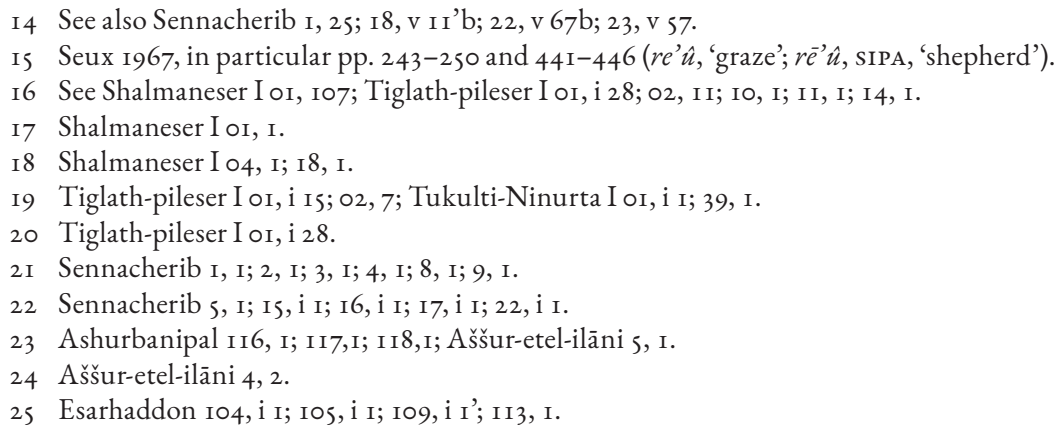


shepherding the land and people', ${ }^{26}$ 'shepherding in truth and justice', ${ }^{27}$ 'shepherding all of the people', ${ }^{28}$ 'you entrus[ted] me with shepherding Assyria', ${ }^{29}$ ' the one who shepherds the four quarters (at the heels of the god Šamaš)', ${ }^{30}$ 'the shepherd who has charge over them, [and the herdsman] who properly administers them'. ${ }^{31}$

Longer developments may also be quoted: "When Aššur, my lord, faithfully chose me to worship him, gave me the scepter for my office of shepherd, (presented) me, in addition, the staff for my office of herdsman, granted me excellence so that I might slay my enemies (and) subdue those who do not fear me, (and) placed upon me the lordly crown; (at that time) I set my foot upon the neck of the lands (and) shepherded the extensive black-headed people like animals. He (Aššur) teaches me just decisions. Like ... the Anunnakū gods ... the gods ... the strength" (Tukulti-Ninurta I oI, I 2I). ${ }^{32}$

The image is also associated with green pastures (cf. Tiglath-pileser III 35, I 2I-35) 33 $^{3}$ or the pacific symbol of the shepherd's staff (Ashurbanipal II5, 20). The royal title undoubtedly bears a territorial/cosmic dimension, a democratic one in the sense that the king is committed to his people, and, finally, a religious and cultic dimension. While the matter of protection is indeed important and overlaps with the defensive and aggressive leonine aspects, the pacific asset is more essential to the image of the shepherd. Therefore, it becomes clear that the two images of the lion and the shepherd interact with each other and in this way considerably enrich the positive and forceful representation of sovereignty in Assyrian royal inscriptions.

It is also important to consider the spatiality of the images and their intersection as the lion belongs to steppes and deserts, whereas the shepherd is located in more protected spaces and in charge of domestic animals. Indeed, the absence of the Master of animals is notorious in these textual sources all the more so because it is found in the iconographic records of the time, whereas that of the shepherd has never been identified as such. Is it possible that the iconography of the Master of animals reflect precisely this interaction we have analyzed between the leonine image and that of the shepherd?

We have thus shown how the images of the lion, the shepherd and the Master of animals interacted in the sources underlying the representation of power in the Assyrian empire. This interaction - it has to be noted - concerns not only the images themselves, the lion as element $\mathrm{B}$, the shepherd as element $\mathrm{C}$, and the Master of animals as element $\mathrm{D}$, but also the nature of the sources, textual and iconographic. For the king as element $\mathrm{A}$ or, more precisely, the representation of his sovereignty is brought to a fuller definition through the interaction of sources and, what interests us most here, through metaphorical interaction.

26 Sennacherib I, 93; 2, 70; 3, 62; 4, 93; 5, I’; 7, 7'; 8, I9'; 10, 23; I5, viii 19”; I6, viii 64; I7, viii 77; I8, viii I 4 "'b.

27 See also Esarhaddon I04, vi I; I05, vii 42b; I Io, ii' I'.

28 Esarhaddon 109 , i I3'.

29 Esarhaddon 104 , ii 9 b; 105 , ii 22 b; i I 4 , ii 19.

30 Tukulti-Ninurta I or, i I; 05, I; IO, I; I3, I; I6, I.

3 I Tukulti-Ninurta I oI, iv 37; 02, 37; 08, I I'; 09, 28'; 23, 85.

32 See also Tukulti-Ninurta I IO, I5; I 23, I.

33 See also Tiglath-pileser III 35, ii I5'b. 


\section{The Lion in Levantine Sources}

B.A. Strawn has extensively analyzed the image of the lion in ancient sources and more particularly in the Levant. ${ }^{34}$ It thus seems unnecessary in this short contribution to review all the material. Let us recall that the analysis of the lion in the archaeological record of ancient Israel/Palestine from I500-332 BCE shows the common association of the lion with sovereignty and diverse deities. Thus, the presence of lion artifacts in cultic and official contexts is abundant and displays evidence of artistic connections with other regions. Moreover, the image of the lion as trope of threat and power is relatively stable across the different data. The use of the image in relation with Yhwh is similar in many ways in comparative and archaeological contexts: Yhwh is likened to a lion (Isa 38:I3; cf. Lam 3:Io) who has broken the bones of Hezekiah. The lion can also become the lion chaser against those who stalk Israel as a lion (Jer 49:19; Jer 50:44). This is a figure of speech to designate Israel's enemies, a picture of pride, strength, and rapacity (Jer 4:7; 5:6; Joel I:6; Nah 2:12-I4). Finally, lions may be sent against lions ( 2 Kgs 17:25). The use of the lion as an image for the enemy is also similar but somewhat more pronounced in the Hebrew Bible (esp. in the Psa 7:3; I0:9; 17:I2; 22:14, 22). Possible explanations are offered by the author for Yhwh's leonine profile. It could stem from the storm-god composite Baal-Seth or, more probably, from the tradition of violent leonine goddesses (especially Sekhmet and Ištar) or, simply from the use of militant lion metaphors in ancient Near Eastern royal inscriptions.

However, B.A. Strawn shows how the use of the lion imagery in relation to the monarch was muted in the biblical text when compared to other and archaeological materials. This has been rightly developed by Hugh Pyper who insists on the glaring biblical omission of the lion as figure of a monarch: there is no celebration of the king as displaying the power of the lion against his enemies, nor of the king as the great protector of his people against lions, real or metaphorical (except maybe the young David as shepherd slaying lions in I Sam 17:34-37). Kingly/royal and human power or position are thus never praised in metaphors involving the lion. ${ }^{35}$ Obviously this testifies to the highly reworked nature of the biblical text: no human king in the history of Israel is deemed worthy of such metaphor.

\section{The Shepherd in Levantine Sources}

The image of the shepherd has been so extensively studied that it does not seem necessary here to look at the sources over again. ${ }^{6}$ I would like to underline Diana V. Edelman's contribution on the topic from the point of view of rhetorical strategies that might be considered more meaningful in their interactive mode. ${ }^{37}$ Four strategies for expressing Israel's enjoyment of a unique relationship with the deity are explored. Let us recall them: I) Israel as Yhwh's people, nation or treasure that has been chosen, set apart or known; 2)

34 Strawn 2015, 2009, and 2005, in particular pp. 188-192.

35 This is in turn developed by Pyper 2014.

36 George 2015; Bailey 20I4; Baxter 20I I and 2012; Gan 2007; Laniak 2006; Van Hecke (ed.) 2005; Selz 200I; Hunziker-Rodewald 200I; Greer 1999; Derret 1973. 
Israel as Yhwh's flock; 3) Israel as Yhwh's garden; and 4) Israel as Yhwh's covenantal vas$\mathrm{sal} / \mathrm{son}$. These strategies assert and reassure that Israel constitutes a unique group in relation to the deity. Let us take a closer look at the shepherd and flock imagery (cf. Psa 44:I2; 74:I; 77:2I; 78.52; 79:13; 80:2; 95:7; IOO:3; Isa 40:II; Mic 2:I2; 7:I4.): Israel appears as Yhwh's property and possession. In several passages, the deity is said to scatter his own flock, Israel, or strike it with plague (I Chron 21:17; Psa 44:II.22; 74:I; Zech 13:7). In these, Yhwh acknowledges Israel as his and himself as the divine shepherd, with or without an appointed human overseer. In Deutero-Isaiah, the people acknowledge they are sheep who have strayed and followed their own path, implicitly rejecting the one specified by their divine shepherd (Isa 53:6). Such disobedience triggers direct divine intervention to chastise the wayward flock, as in Psa 44:II.22 and Psa 74:I. In this case, the sheep themselves must bear responsibility for straying; there is no shepherd who has been lax or inattentive to be punished in their stead. Interestingly, in other passages the scattering is done by another, either a foreign king or a domestic kingly shepherd entrusted with their care, feeding, and protection but who have not carried out their appointed tasks ( $\mathrm{I}$ Kgs 22:17 = 2 Chron I8:16; Jer 13:20; Ezek 34:I-34). These passages assume that Yhwh is the only owner of Israel and so controls its fate as well as the fate of those appointed to shepherd it on earth. The interesting point of the analysis is to bring out clearly how the same image can be nuanced in very different narratives and how roles may be exchanged: the good shepherd might not in fact be always so good as he disperses as well as gathers his own property and possession. I would now like to pursue the analysis and bring in the lion metaphor as it is expanded in a particular manner, in interaction with that of the shepherd in the book of Amos.

At this point and in contradistinction to Assyrian sources, the shepherd metaphor in biblical texts is lengthily reworked and not necessarily positive, while the lion metaphor, as we have shown, is absent in relation to human kingship. Certainly, the nature of the sources account for such differences, as Assyrian royal inscriptions are primary sources contrary to biblical texts transmitted over centuries and copied by skillful as well as political scribes. Interestingly biblical scribes did not fear to reflect upon ancient Near Eastern and common royal or divine images: they did not fear in fact to deconstruct them.

\section{The Book of Amos}

The first collection of the book of Amos is introduced by verse 2: "And Yhwh said (ויאמר יהוה): from Zion he roars (מציון ישאג), and from Jerusalem he utters his voice; the pastures of the shepherds wither / lament (ואבלו נאות הרעים), and the top of Carmel dries up." We notice at once the association of the images of the lion (through roaring) and of the shepherds (through the pastures). We also notice that after the incipit of the first verse, one might consider verse 2 as opening not only the first collection of oracles but also the whole booklet, so much so that the leonine figure runs through it (I:2; 3:4.8.12; 5:19; 9:3). ${ }^{38}$ Even more, as the subject of the verb 'to roar' may have remained undetermined (according to the Massoretic accentuation), the interpretation of the figure is somehow

38 Strawn 2005, 2009 and 2015; Nahkola 201 I. 
suspended, though the subject, that is, Yhwh is in close relation. Let us follow now the narrative thread of this leonine image before we propose an interactive interpretation of this metaphor and that of the shepherd. The lion reappears again in an oracle of condemnation framed in rhetorical interrogations: "Does a lion roar in the forest, when it has no prey? Does a young lion cry out from its den, if it has caught nothing?” (3:4).

"The lion has roared; who will not fear? The Lord Yhwh has spoken; who can but prophesy?" (3:8).

"Thus says Yhwh: As the shepherd rescues from the mouth of the lion two legs, or a piece of an ear, so shall the people of Israel who live/reign in Samaria be rescued, with the corner of a couch and part ${ }^{39}$ of a bed" (3:I2).

The announcement of the great tragedy striking Samaria is sustained by the image that has introduced the whole book ( $1: 2)$ and characterized the oracles the nations, the image of the lion (3:4.8.12). But whereas the interpretation of the leonine figure could remain open in verse $\mathrm{I}: 2$, it is specified as the subject is now clearly named (3:4.8). Here one can say that the metaphor is extended: if the lion is first named in a comparison of a proverbial type in 3:4, in the course of the rhetorical questions, it is indeed the divine figure that is contemplated: the prey that Israel has become is already in Yhwh's claws and the evil has been done! Verse 3:8 confirms the verdict of the lion-Yhwh but also brings in the figure of the prophet as a roaring one. Moreover, the shepherd comes in as he saves or rather cannot save his flock from the lion (3:I2). ${ }^{40}$ The indetermination of verse $\mathrm{I}: 2$ is indeed verified as the action of roaring is closely associated not only with the divine subject but also with the prophet.

If these first oracles in the book share common images, their association and the new meaning they take on is all the more striking. Striking, also, is the ironic tone which, little by little, colors them. Indeed, the metaphor of the lion that closely associates that of the shepherd in 3:12 presents this last figure, by definition a figure of protection, as one of failure: if the shepherd saves two legs and a piece of ear, it means that the animal is lost, is dead. It is true however that these 'saved' parties testify to the shepherd that he is not responsible for the loss of the animal, as the Covenant Code makes clear (cf. Exod 22:12). A figure of failure but justified, we could say! What can the shepherd do against the lion? Still, one must underline the use of the verb 'to save' that does point to the fact that all is not lost. The responsibility of the shepherd is engaged but he is not wronged. It is here that the irony creeps into the text, since what has been saved is in fact dead! And this irony continues: "as if someone fled from a lion, and was met by a bear; or went into the house and rested a hand against the wall, and was bitten by a snake" (5:19). The irony is striking and bitter. This time the lion may only terrify its prey, it cannot kill it! But the association

39 See Eidevall 2017, in particular pp. 130-131, 133. Notice that the Septuagint reads 'priests' where the Hebrew reads 'bed' (שרע) and translates "in the city of Damascus” where the parallelism would imply some part of a bed.

40 The image of v. I2 seems to refer to some judicial usage: when a shepherd (pro)claimed his flock to have been attacked, he had to justify the attack to the owner of the flock by showing the animal remains (Exod 22:9-I2; cf. Gen 37:29-36. See Hadjiev 2008). 
or interaction between the lion and the shepherd goes one step further, if one remembers that Amos himself has been defined as a shepherd. The title or function of Amos is given in the opening of the book (עמוס אשר היה בנקדים, I:I): Amos is nōqèd, a term that is usually understood as 'shepherd' or 'breeder', the unique other reference to the term being found in 2 Kgs 3:4 concerning the king of Moab. This understanding, however, is assured from parallels in other Semitic languages, Ugaritic, Akkadian and Arab, ${ }^{41}$ as well as by the term boger found in the narrative of the expulsion of Amos from the sanctuary of Bethel (7:I4). בוקר אנכי (ויקחני יהוה מאחרי הצאן 7,5 cf. 2 S 7:8). The image of the shepherd is, as we have just seen, one of strong political and theological implication: kings like divine shepherds are called to conduct and protect their people. In the biblical texts, shepherds of their people, kings and prophets are called by the deity Yhwh, himself the shepherd par excellence (Jer 3:I7; I3:I7; 23:I-6; 31:IO-I4; Ezek 34; Hos 13:4-8; etc.). There is without doubt a common motif hereby recontextualized in a way that it may constitute nothing less than a critique of the prophetic institution in the time of the monarchy in Israel..$^{43}$ However, my purpose here is to insist on the interaction between the leonine metaphor and the shepherd's one along with the interaction between the subjects that are Yhwh and his prophet. By metaphorical play and interaction, the two subjects, Yhwh (A) and Amos (A') are brought into relation with the lion (B), through the actions of roaring and killing, on the one hand, and the shepherd $(C)$, as protector who eventually ends in failure, on the other. In this way, the meaning of the metaphors is not so much in their separate study $\left(A / B ; A / C ; A^{\prime} / B ; A^{\prime} / C\right)$ but in their interaction $\left(\mathrm{A}-\mathrm{A}^{\prime} / \mathrm{B} / \mathrm{C}\right)$. The originality lies in the close association of the two subjects as well as in the interaction of the two metaphors that are the lion and the shepherd. Lion's and shepherd's imagery lend their qualities to divine as well as prophetic sovereignty and enrich considerably their representation. The absence of a human monarch in this interaction seems obvious in light of the historical failure of both northern and southern kingdoms. The image depicting the shepherd, whether divine or prophetic, as a failure in the end is very interesting indeed! Biblical scribes in the Book of Amos have made use of common images and metaphors but they have blurred the referent of these images and have deconstructed the intended meaning: when the prey has died with two legs only left, what could anyone do? The effect is of the greatest irony: all intended metaphorical content is lost.

4I See Wilson 2018, specifically p. 319; Craigie 1982.

42 Dijkstra 200I.

43 Schmid 2018, in particular p. I09: "But the basic problem of institutionally-rooted prophecy becomes clear here, since the expectations imposed upon it can end up determining its content-a situation from which contemporary experts are likewise not immune. (...) The prophet Amos states, "I am no prophet." This statement is only understandable against the sociological background that 2 Kings 22 illustrates. Amos does not deny that he utters prophecies, but he does distance himself from the institutional prophets who provide their expertise about future contingencies." 


\section{Concluding Remarks}

As a conclusion, let us sum up our analysis and results. We have shown how the images of the lion, the shepherd and the Master of animals interacted in Mesopotamian sources making greater sense of the representation of power especially in the Assyrian empire. This interaction concerned the images themselves as well as the nature of the sources, textual and iconographic.

In contradistinction to Assyrian sources, it has been shown how the shepherd metaphor in biblical texts was lengthily reworked and is not necessarily positive, while the lion metaphor is absent in relation to human kingship. Certainly, the nature of the sources account for such differences, as Assyrian royal inscriptions are primary sources contrary to biblical texts transmitted over centuries. However, biblical scribes were not afraid of reflecting upon common royal or divine images, even to the point of ironically deconstructing them as the book of Amos testifies.

Therefore, the force of these metaphors lies in their association: they make full sense in their interactive interpretation, one together with other. This multiplication of sense gives to the representation of power and sovereignty something absolute: not being limited by one unique image and its interpretation, it is enriched by multiple images which interactive interpretation can only add to the cosmic and indeed divine representation of kinship, or not, as in the book of Amos.

\section{Bibliography}

Albenda, P. 1972, “Ashurnasirpal II Lion Hunt Relief BMı24534”, Journal of Near Eastern Studies 31, 167-178.

-. 1974, "Lions on Assyrian Wall Reliefs", Journal of the Ancient Near Eastern Society of Columbia University 6, I-27.

-. 2008, "Assyrian Royal Hunts: Antlered and Horned Animals from Distant Lands", Bulletin of the American Schools of Oriental Research 349, 6I-78.

Bailey, K.E. 2014, The Good Shepherd: A Thousand-Year Journey from Psalm 23 to the New Testament, Downers Grove: InterVarsity Press.

Baxter, W. 20II, "Matthew, Mark, and the Shepherd Metaphor: Similarities, Differences, and Implications", in: E.M. Becker - A. Runesson (eds.), Mark and Matthew, Comparative Readings: Understanding the Earliest Gospels in their First-century Settings, Tübingen: Mohr Siebeck, 263-282.

-. 2012, Israel's Only Shepherd: Matthew's Shepherd Motif and his Social Setting, Library of New Testament Studies/Journal for the Study of the New Testament Supplement Series 457, London: T\&T Clark.

Cassin, E. 1981, "Le roi et le lion," Revue de l'histoire des religions 198, 355-40I.

Collins, B.J. 1998, "Hattusili I, the Lion King," Journal of Cuneiform Studies 50, I5-20.

Counts, D.B. 20Io, "Divine Symbols and Royal Aspirations: The Master of Animals in Iron Age Cypriote Religion”, in: D.B. Counts - B. Arnold (eds.), The Master of Animals in Old World Iconography, Budapest: Archaeolingua Alapítvány, I35-I5O.

Counts, D.B. - Arnold, B. (eds.) 2oio, The Master of Animals in Old World Iconography, Budapest: Archaeolingua Alapítvány. 
Counts, D.B. -Arnold, B. 2oio, "Prolegomenon: The Many Masks of the Master of Animals", in: D.B. Counts - B. Arnold (eds.), The Master of Animals in Old World Iconography, Budapest: Archaeolingua Alapítvány, 9-24.

Craigie, P.C. 1982, "Amos the noged in the Light of Ugaritic", Studies in Religion/Sciences Religieuses II, 29-33.

Derrett, J.D.M. 1973, “The Good Shepherd: St. John's Use of Jewish Halakah and Haggadah", Studia Theologica 27, 25-50.

Diamond, E. 2003, "Lions, Snakes, and Asses: Palestinian Jewish Holy Men as Masters of the Animal Kingdom", Jewish Culture and Society under the Christian Roman Empire, Leuven: Peeters, 254-284.

Dijkstra, M. 200I, "I am neither a prophet nor a prophet's pupil': Amos 7:9-I7 as the Presentation of a Prophet like Moses", in: J.C. de Moor (ed.), The Elusive Prophet, Leiden: OTS, IO5-I28.

Edelman, D.V. 2016, "YHWH's Othering of Israel”, in: E. Ben Zvi - D. Edelman (eds.), Imagining the Other and Constructing Israelite Identity in the Early Second Temple Period, The Library of Hebrew Bible/Old Testament Studies 59I, London: T\&T Clark, $4 \mathrm{I}-69$.

Eidevall, G. 20I7, Amos: A New Translation with Introduction and Commentary, Anchor Yale Bible $24 \mathrm{G}$, New Haven: Yale University Press.

Gan, J. 2007, The Metaphor of Shepherd in the Hebrew Bible: A Historical-Literary Reading, New York: University Press of America.

George, J.C. 2015, The Metaphor of Shepherd in the Gospel of Mark, Frankfurt am Main: Peter Lang.

Greer, R. 1999, “The Good Shepherd: Canonical Interpretations in the Early Church?”, in: B.S. Childs (ed.), Theological Exegesis, Grand Rapids: William B. Eerdmans Publishing Co., 306-330.

Hadjiev, T.S. 2008, "The Context as Means of Redactional Reinterpretation in the Book of Amos", Journal of Theological Studies 59, 655-668.

Haubold, J. 20I5, “Shepherds of the People': Greek and Mesopotamian Perspectives”, in: R. Rollinger - E. van Dongen (eds.), Mesopotamia in the Ancient World: Impact, Continuities, Parallels, Proceedings of the Seventh Symposium of the Melammu Project held in Obergurgl, Austria, November 4-8, 2013, Münster: Ugarit-Verlag, 245-254.

Heil, J.P. 2006, "Jesus with the Wild Animals in Mark I:I3", Catholic Biblical Quarterly $68,63-78$.

Hunziker-Rodewald, R. 20oI, Hirt und Herde. Ein Beitrag zum alttestamentlichen Gottesverständnis, Beiträge zur Wissenschaft vom Alten und Neuen Testament I55, Stuttgart: Kohlhammer.

Keel, O. - Uehlinger, Ch. 2ooI, Dieux, déesses et figures divines: les sources iconographiques de l'bistoire de la religion d'Israël, Paris: Cerf.

Laniak, T.S. 2006, Shepherds After My Own Heart: Pastoral Traditions and Leadership in the Bible, Downers Grove: Apollos/InterVarsity Press.

Nahkola, A. 20II, "Amos Animalizing: Lion, Bear and Snake in Amos 5.19”, in: A.C. Hagedorn - A. Mein (eds.), Aspects of Amos: Exegesis and Interpretation, London: T\&T Clark, 83-IO4.

Pyper, H. 20I4, "The Lion King: Yahweh as Sovereign Beast in Israel's Imaginary”, in: J.L. Koosed (ed.), The Bible and Posthumanism, Atlanta: Society of Biblical Literature, 59-74. 
Schmid, K. 2018, "Prognosis and Postgnosis in Biblical Prophecy", Scandinavian Journal of the Old Testament 32, 106-120.

Selz, G.J. 20oI, “'Guter Hirte, Weiser Fürst': Zur Vorstellung von Macht und zur Macht der Vorstellung im altmesopotamischen Herrschaftsparadigma”, Altorientalische Forschungen 28, 8-39.

-. 2018, "Intimate Relations Reconsidering Backgrounds of the Mesopotamian Mis-

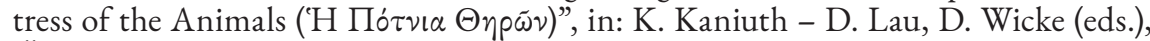
Übergangszeiten. Altorientalische Studien für Reinhard Dittmann anlässlich seines 65. Geburtstags, marru I, I43-151.

Seux, M.J. 1967, Épithètes royales akkadiennes et sumériennes, Paris: Letouzey\&Ané.

Seyer, M. 2006, "The Royal Hunt - The Symbolical Meaning of an Ancient Topos", in: A. Prinz (ed.), Hunting Food - Drinking Wine, Proceedings of the XIX Conference of the International Commission for the Anthropology of Food, Poysdorf, 4.-7. 12.2003, Wiener ethnomedizinische Reihe 3, Münster: LIT, 7I-I98.

- 2007, Der Herrscher als Jäger: Untersuchungen zur königlichen Jagd im persischen und makedonischen Reich vom 6. - 4. Jahrbundert v. Chr. sowie unter den Diadochen Alexanders des Grossen, Wiener Forschungen zur Archäologie II, Wien: Phoibos.

Strawn, B.A. 2005, What Is Stronger than a Lion?: Leonine Image and Metaphor in the Hebrew Bible and the Ancient Near East, Orbis Biblicus et Orientalis 212, Fribourg/ Göttingen: Academic Press Fribourg/Vandenhoeck\&Ruprecht.

- 2009, "Whence Leonine Yahweh?: Iconography and the History of Israelite Religion", in: M. Nissinen - Ch.E. Carter (eds.), Images and Prophecy in the Ancient Eastern Mediterranean, Göttingen: Vandenhoeck\&Ruprecht, $5 \mathrm{I}-85$.

-. 2015, "Lion Hunting in the Psalms: Iconography and Images for God, the Self, and the Enemy”, in: I.J. de Hulster - B.A. Strawn - R.P. Bonfiglio (eds.), Iconographic Exegesis of the Hebrew Bible-Old Testament: An Introduction to its Method and Practice, Göttingen: Vandenhoeck\&Ruprecht, 245-26r.

Van Hecke, P. 2005, "Pastoral Metaphors in the Hebrew Bible and its Ancient Near Eastern Context”, in: R.P. Gordon - J.C. de Moor (eds.), The Old Testament in its World, Leiden: Brill, 200-217.

Watanabe, C.E. 1998, "Symbolism of the Royal Lion Hunt in Assyria", in: J. Prosecky (ed.), Intellectual Life of the Ancient Near East, Praha: Academy of Sciences of the Czech Republic Oriental Institute, 439-450.

-. 2000, "The Lion Metaphor in the Mesopotamian Royal Context", Topoi suppl. 2, 399-409.

Wilson, R.R. 2018, "Prophecy and the State in 8th-Century Israel: Amos and Hosea", in: C.A. Rollston (ed.), Enemies and Friends of the State: Ancient Prophecy in Context, Winona Lake: Eisenbrauns, 313-328.

\section{Online resources}

The Royal Inscriptions of Assyria online (RIAo) Project: http://oracc.museum.upenn.edu/ riao/ 